\title{
sciendo
}

\section{Mediating Role of Dynamic Capabilities on the Relationship between Human Resource Development and Organizational Effectiveness}

\author{
Mohanad Ali KAREEM ${ }^{1}$ and Hayder Abdulmohsin MIJBAS ${ }^{2}$ \\ ${ }^{1}$ Kaposvár University, Faculty of Economic Science, Doctoral School of Management in Kaposvár, Hungary, \\ mohannadali25@gmail.com (corresponding author). \\ ${ }^{2}$ Al-Mustansiriyah University, Baghdad, Iraq, Hader.hije@uomustansiriyah.edu.iq
}

\begin{abstract}
Background and purpose: The recent literature established that human resource development (HRD) is significantly related to organizational effectiveness (OE). In rapidly changing environments, the organizations should strive to address the shifts in the environment and cope with markets conditions through developing dynamic capabilities, in return, enhance organizational effectiveness. The main purpose of this study is to examine the mediating role of dynamic capabilities on the relationship between human resources development and organizational effectiveness in the Iraqi public universities context.

Design/Methodology/Approach: Data were collected through an online questionnaire survey from 215 employees executive and non-executive employees working in the selected public universities in Iraq. Structural equation modeling (SEM) was employed to test the proposed research model.

Results: The analyzed data supported all the hypothesized relationships of the study. This study finds that HRD practices have a significant influence on organizational effectiveness and dynamic capabilities. Further, dynamic capabilities significantly influence on organizational effectiveness. Also, the study empirically supports the mediating effect of dynamic capabilities on the relationship between HRD practices and organizational effectiveness.

Conclusion: In the literature, there is still a lack of how HRD practices impact on organizational effectiveness through the mechanisms of dynamic capabilities. Therefore, this research contributes to the literature by pointing out the mediating role of dynamic capabilities on the relationship between HRD and organizational effectiveness. Based on the existing literature and empirical results, the study provides the theoretical and practical implications which are further discussed in detail.
\end{abstract}

Keywords: Human resource development, Dynamic capabilities, Organizational effectiveness

\section{Introduction}

Business environments today, characterized by knowledge-based competition and rapidly changing markets, require organizations use effective strategies to invest and maximize knowledge and skills. Organizations continually attempt to leverage human resource to achieve organizational success. The concept of human resource development (HRD) has emerged as a strategy to develop and improve employee's knowledge, skills, and abilities to enhance organizational effectiveness (Gberevbie, 2012). Developing HRD practices have the potential to improve organizational performance. Some empirical researches have proved that such as (Brockbank, 1999; Garavan, 2007; Clardy, 2008 and Han et al., 2006) emphasis that

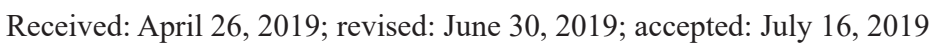


HRD as a set of responsibilities, competencies, practices, programs, initiatives that have a potential influence on organizational effectiveness. Also, Several researchers (McCracken \& Wallace.2000; Otoo et al. 2018; Shoo 2016; Alagaraja \& et al. 2015; and Nilsson \& Ellstrom 2012) established that there is a significant relationship between human resource development and organizational effectiveness. Nevertheless, in rapidly changing environments it is compulsory that organizations are prepared for change and have the human capital to meet and cope with the environmental turbulence. HRD plays a key role to maintain and develop human resources in accordance with the changing direction of corporate goals and objectives (Shanahan et al. 2012). Hence, in such an environment, superior organizational effectiveness based on organizations ability to integrate, build and reconfigure internal and external resource to address environmental changes, the process of which is termed as dynamic capabilities. Dynamic capabilities contribute to organizational effectiveness through an effective modification of existing operating routines, enabling the organization to adopt environmental changes by way of sensing environmental conditions, learning response patterns and reconfiguring operating routines. (Teece et al.,1997). Furthermore, many strategic management researchers (Lado and Wilson 1994; Lepak and Snell 1999; Wright et al. 2001) argue that dynamic capabilities can enhance and sustain organizational effectiveness over time when they are developed with complementary human resource development practices. Despite this progress, there is still a lack in the literature about an understanding of the mediating mechanisms of dynamic capabilities on the relationship between HRD practices and organizational effectiveness. More recently, studies such as (Wang et al. 2011; Wilhelm et al.,2015; and Helfat et al.,2007) focus on how developing dynamic capabilities by human resource. Based on the knowledge of the authors there were no studied investigated the alternative relationships except Lopez-Cabrales et al. (2017) investigate the relationship between dynamic capabilities and HRM considering the mediating role of leadership styles Hence, the purpose of this study is to investigate the mediating role of dynamic capabilities on the relationship between human resource development and organizational effectiveness in the selected public universities context. Consequently, this study tries to address this gap through proposing an empirical model that demonstrates dynamic capabilities constructs i.e. sensing capabilities, learning capabilities and reconfirmation capabilities mediate the relationship between HRD constructs i.e. talent development, training and development, organizational development, and career development and organizational effectiveness. In addition to, this study is novel which tries to meet the need of the higher education sector in Iraq to such studies, for its influential role in society.

The remainder of the article is organized as follows: the first section presents the introduction. The second section describes the literature review. The third section presents the research methodology. The fourth section shows the data analysis and results. The last section presents a discussion of the findings including theoretical and practical implications, study limitations and future research.

According to the discussion above, the following questions guided the study design:

company B:

- Do HRD practices influence organizational effectiveness?

- Do HRD practices influence dynamic capabilities?

- Do dynamic capabilities influence organizational effectiveness?

- Do dynamic capabilities mediate the relationship between HRD practices and organizational effectiveness?

\section{Literature review and hypotheses development}

\subsection{Human resource development contributions to organizational effectiveness and dynamic capabilities}

This study argues that HRD practices have a direct impact on organizational effectiveness regardless of environmental changes. Several researchers such as (Mohammed 2006; Alagaraja et al., 2015; and Shoo 2016) have discussed this issue. Mohammed (2006) argues that the success and progress of an organization lie in its ability to explore and attract the talent and potentials of its workforce, and this is can be achieved through the HRD practices. Riordan el at (2005) argue that appropriate, ongoing training and development and career development enable employees to develop the skills, abilities, and knowledge required for effective performance, in turn, improve organizational effectiveness. Likewise, Adhikari, (2010) indicates that HRD supports and strengthening of an organization's human capital base by increasing the level of knowledge, skills, and capabilities of individuals in an organization and thus contributes to improved performance and competitive advantage. Sahoo (2016) argues that HRD practices training, career development, and performance management have an impact on the building of employee competencies which, in turn, enhance organizational effectiveness. Agwu \& Ogiriki, (2014) argue that use of HRD practices training and development, organizational development and career development lead to improving organizational effectiveness through improvement in individual, 
group knowledge, skills, attitudes, and behavior. Otoo et al., (2019) argue that HRD practices such as performance appraisal, career development, and training and development have a significant impact on organizational effectiveness through their impact on employee performance. Similarly, Swanson and Holton (2009) emphasize that HRD practices improve employee competence, in turn, enhance organizational effectiveness.

Alagaraja et al., (2015) state that there are five significant approaches for investigating the linkage of HRD and organizational performance and effectiveness: First, the best-fit approach which is an emphasis that HRD practices must convenient the characteristics of the organization. Second, the best-practice approach suggests HRD practices have a positive influence on performance and these practices can be adopted by other organizations for improving performance. Third, a combination of a best-fit approach and best-practice approach suggests that HRD contributions to the organizational effectiveness and performance through the combining of both the approaches. Fourth, the stake holder's perception approach indicates that investigating the impact HRD on organizational effectiveness and performance through the contribution of stakeholder perceptions. Fifth, focus on the aforementioned approaches.

Nevertheless, in the rapidly changing environment, the organizations need to address environmental shits and changes through developing so-called dynamic capabilities. This study states that HRD practices have a significant impact on building dynamic capabilities. However, the relationship between HRD and dynamic capabilities is still under developing (Wright and Snell, 2009). Only a few studies address the linkage between HRD and dynamic capabilities (Teece et al., 1997; Eisenhardt and Martin, 2000; Zahra \& George, 2002; Teece, 2007; Hsu and Wang, 2012) have confirmed that learning, sensing, integrating, and reconfiguration capabilities of the organization are highly lie on employee's knowledge, skills, abilities and experienced these are the outcome of human resources development practices. Likewise, Garavan et al. (2016) argue that HRD practices help employees to work effectively in different environmental conditions and improve knowledge, skill, behavioral, and attitudinal outcomes that provide employees with the flexibility to respond to shifts in the environment. When organizations use human resource development practices to develop and leverage human capital, in turn, may catch the benefits of complementarities and co-specialization to develop dynamic capabilities (Barney 1991; Grant 1996). Human resource development practices such as training and development performance evaluation and compensation systems have the potential to enhance the dynamic capability and maintain the sustainable competitive advantage of organizations (Yan and Gao,2016). In changing environmental conditions HRD practices can increase the flexible organization, organizational learning, resources integration, and environmental perception (Chengcheng, 2010). Teece et al., (1997) de- fine dynamic capabilities as the firm's ability to integrate, build, and reconfigure internal and external competencies to address rapidly changing environments. Garavan (2007) argues that HRD supports the development of dynamic capabilities that are critical in developing and maintaining a sustained competitive advantage.

This study argues that HRD practices have a direct impact on dynamic capabilities. In order to explore in an integrated way, the linkage between HRD and dynamic capabilities, this study determined the dynamic capabilities in three measured dimensions: sensing capability, learning capability, and reconfiguration capability. Sensing capability is the firm's ability constantly to discover, explore and interpret opportunities in the environment (Pavlou and El Sawy 2011). Therefore, HRD helps organizations to make sense of shifts in the environment, set plans, and seize opportunities (Garavan et al., 2016). Eisenhardt \& Martin, (2000) state that learning capability is the firm ability's acquiring or creating specific knowledge necessary to seize the identified opportunities. HRD practices improve learning mechanisms such as experience accumulation, knowledge creation, and sharing knowledge are critical to the formation of learning capability (Zollo and Winter (2002). Reconfiguration capability refers to the recombination and transformation of existing resources that enable firms to address the changes in market conditions (Teece, 2007). HRD enhances the creation of new capabilities, configure assets and organizational development to address the markets and technologies changes.

This study contributes to the theory and research on human resource development contribution to organizational effectiveness and dynamic capabilities by examining the direct impact of HRD practices on organizational effectiveness and dynamic capabilities. Based on the aforementioned contributions, this study hypothesizes

H1: HRD practices have a significant impact on organizational effectiveness.

H2: HRD practices have a significant impact on dynamic capabilities. 


\subsection{Dynamic capabilities and organizational effectiveness}

The dynamic capabilities concept has emerged due to the changes in environments and market. Scholars (Hammer, 2001 and Zott, 2003) have stated that to sustain a competitive advantage in a rapidly changing environment, organizations need to develop dynamic capabilities for improving core competencies and enhance organizational effectiveness. This study argues that dynamic capabilities have a significant potential on organizational effectiveness. But, The association between dynamic capabilities and organizational effectiveness and performance is still unclear (Zhou \& Zhou, 2017). However, some scholars (Teece et al. 1997; Eisenhardt \& Martin, 2000; López, 2005 and Wilden et al, 2013) argue that dynamic capabilities enable organizations to link the resource base with environmental shifts, create market change, and facilitate resource access and resource development, in turn, enhance the organizational effectiveness. Teece (2007) argues that dynamic capabilities enable an organization to achieve competitive advantage in a changing business environment through developing specific capabilities and competencies which support organizational effectiveness and performance. Fainshmidt et al., (2016) argue that dynamic capabilities are significantly related to organizational effectiveness. The scholars (Rehman and Saeed, 2015; Takahashi et al.,2016 and Zhou and Zhou,2017) emphasize that dynamic capabilities have an indirect impact on the organizational effectiveness through mediated by the development of operational capabilities. Based on the above discussion, the third hypothesis can be derived as follows:

H3: Dynamic capabilities have a significant impact on organizational effectiveness.

\subsection{Human resource development, dynamic capabilities, and organizational effectiveness}

The aforementioned literature have established that HRD practices significantly influence organizational effectiveness. But, in rapidly changing environments, HRD is often not enough to support organizational effectiveness (Teece et al., 1997 and Aminu and Mahmood, 2015). Thus, this study, argues that in such dynamic environment HRD practices have potential to influence organizational effectiveness indirectly through mediating of dynamic capabilities. Moreover, due to rapidly changing in the environment, the organizations should prepare for the change to address the shifts in the environment and cope with markets conditions. The originations strive to develop capabilities to integrate, build, and reconfigure internal and external competencies to address rapidly changing environments, in return, support make decisions within the organization which has the potential to enhance organizational effectiveness and performance (Eisenhardt and Martin, 2000; Teece, 2007). HRD plays a key role to maintain and develop human resources in accordance with the changing direction of corporate goals and objectives (Shanahan et al. 2012). HRD contributes to the creation of new capabilities and the renewal and reconfigures of existing capabilities to cope with dynamic environments (Zollo and Winter 2002). Therefore, it is significant to study the mediating role of dynamic capabilities in the relationship between HRD and organizational effectiveness. However, due to limited studies in the literature, there is still confusion about how dynamic capabilities mediate the relationship between HRD and organizational effectiveness. Even though, there are few researchers (Lado and Wilson 1994, Tseng and Lee, 2014; Aminu and Mahmood, 2015; and Garavan et al, 2016) investigated this issue. Furthermore, (Lado and Wilson 1994; Wright et al. 2001) argue that dynamic capabilities can ensure sustainable organizational effectiveness when they are developed through HRD practices. Similarly, Garavan et al. (2016) argue that HRD practices, structures, and processes can, develop unique dynamic capabilities that enhance the organizational effectiveness in the environmental turbulence. Wang et al.,(2012) argue that to maintaining dynamic capabilities requires organizations to develop the human resources that enable them to improve the organizational effectiveness and preference and in correspondence with the dynamic environment. As such, the present study hypothesized that dynamic capabilities mediate the relationship between human resources development practices and organizational effectiveness. The hypothesis is presented as follows:

H4: Dynamic capabilities significantly mediate the relationship between human resources development practices and organizational effectiveness.

Considering the above-mentioned hypothesizes, the study proposed the following model as a conceptual model of this paper (Figure 1). 


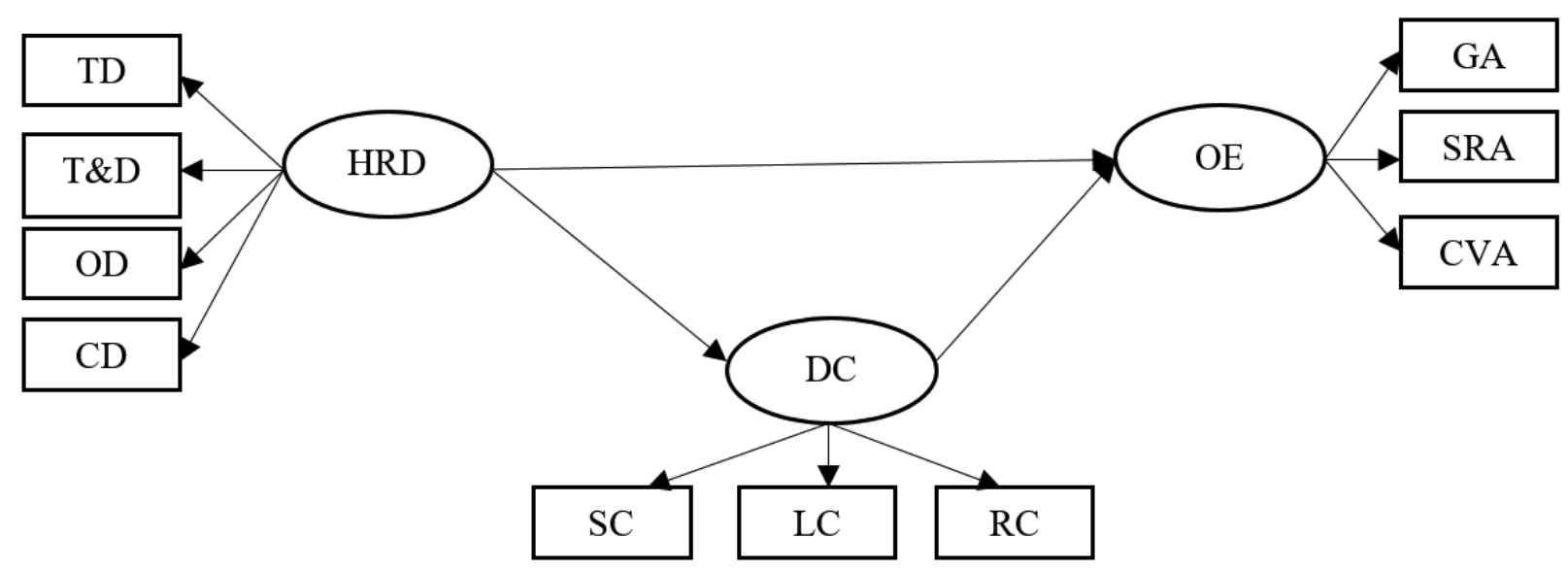

Figure 1: Conceptual model

HRD=Human Resource Development, DC=Dynamic Capabilities, $\mathrm{OE}=$ Organizational Effectiveness, TD=Talent Development, T\&D=Training \& Development, $\mathrm{OD}=$ Organizational Development, $\mathrm{CD}=$ Career Development $\mathrm{SC}=$ Sensing Capability, $\mathrm{LC}=$ learning Capability $=$ Reconfiguring Capability, $\mathrm{GA}=$ Goal Approach, $\mathrm{SRA}=$ System Resource Approach, CVA=Competing Values Approach.

\section{Research methodology}

\subsection{Research design, sampling and data collection}

To test the proposed model, this research employed a deductive approach based on a quantitative method. The purpose of this quantitative method is to examine the mediating role of dynamic capabilities on the relationship between human resource development and organizational effectiveness. According to Sekaran \& Bougie, (2013) quantitative method is appropriate to use in hypotheses testing of the relationship between independent and dependent variables. The study took place in top ten Iraqi public universities. For collecting the primary data this research used the survey method because it is considered an economical and efficient method to gather quantitative data concerned to a given population for the purpose of generalizing the result. This study employed a web-based survey for collecting data from the sample of the study. An online questionnaire was developed based on the literature (see table 2 and appendix 1 ) to collect the primary data. The questionnaire was created by the google-forms tool, which is commonly used by researchers for collecting data. The web-based questionnaires were distributed through E-mail designed to collect the primary data from the selected universities. The sample is including a number of deans, heads of departments, faculty members, principals, and administrative staff which seems to provide a corresponding sample for conducting data collecting and analyzing. The questionnaire was distributed to around 342 employees, out of which 215 completed questionnaires were obtained, with a response rate of $62.86 \%$ of the respondents. The demographic data of the respondents are presented in Table 1. It shows that out of the 215 respondents, $(76.74 \%)$ were males. The majority of the respondents $(44.65 \%)$ were in the age category within 31-40 years. Most of the respondents at $(61.86 \%)$ were non-executive designation and (38.13) were an executive designation. The majority of the respondents $(47.44 \%)$ were holders Ph.D. degree while $(40.46 \%)$ were holders master's degree and $(12.93 \%)$ were holders bachelor's degree. A little lower than half of the respondent (41.39\%) had work experience 11-20 years.

\subsection{Data analysis procedure}

Data analysis was conducted to address the research questions, objectives and hypotheses. Statistical Package for Social Science (SPSS) version 23 and the Analysis of Moment Structures (AMOS) software version 24 were used for analyzing data. Before conducting data analysis, the data preparation was done on the completed questionnaires by editing, coding, entering and cleaning the data. Descriptive statistics such as the frequency and percentage, mean, standard deviation, were used to provided data summarization of demographic characteristics of respondents. Also, the Pearson correlation coefficient was used to describe the correlations among the variables. Confirmatory factor analysis (CFA) was carried out to assess the validity of the measurement model, fitting and modification. 
Table 1: The demographic data of the respondents

\begin{tabular}{|l|l|l|l|}
\hline Item & & Frequency & Percentage \\
\hline \multirow{4}{*}{ Gender of the respondent } & Male & 165 & 76.74 \\
\cline { 2 - 4 } & Female & 50 & 23.25 \\
\hline \multirow{5}{*}{ Age of the respondent } & $20-30$ years & 34 & 15.81 \\
\cline { 2 - 4 } & $31-40$ years & 96 & 44.65 \\
\cline { 2 - 4 } & $41-50$ years & 65 & 30.23 \\
\cline { 2 - 4 } & $51-60$ years & 14 & 6.51 \\
\cline { 2 - 4 } & More than 61 years & 6 & 2.79 \\
\hline \multirow{5}{*}{ Educational achievements } & Executive & 82 & 38.13 \\
\cline { 2 - 4 } & Non-Executive & 133 & 61.86 \\
\hline \multirow{5}{*}{ Work Experience } & Bachelor's Degree & 26 & 12.93 \\
\cline { 2 - 4 } & Master's Degree & 87 & 40.46 \\
\cline { 2 - 4 } & Ph.D. Degree & 102 & 47.44 \\
\hline & Less than 5 years & 31 & 14.41 \\
\cline { 2 - 4 } & 5-10 years & 63 & 29.30 \\
\cline { 2 - 4 } & $11-20$ years & 89 & 41.39 \\
\cline { 2 - 4 } & More than 21 years & 32 & 14.88 \\
\hline
\end{tabular}

Also, Cronbach's Alpha was used to examine the reliability of the scale items. The overall model fit was assessed using five goodness-of-fit indices, namely the chi-square/ degree of freedom $(\chi 2 / \mathrm{df})$ ratio, the comparative fit index (CFI), the Tucker-Lewis index (TLI), the goodness of fit index (GFI), the root means square error of approximation (RMSEA). In addition, squares structural equation modeling (SEM) was used to test empirically the proposed hypotheses. SEM is commonly used in the social sciences because of its ability to explain the relationships between unobserved constructs (latent variables) from observable variables (Henson \& Roberts., 2006). SEM is comparable to common quantitative methods, such as correlation, multiple regression, and analysis of variance to estimate and test the relationships among constructs.

\subsection{Instrumentation development and measures}

The questionnaire was developed based on an extensive review of the literature related to the topic of the study. The questionnaire comprises of two sections. Section one collects participant \& institutional background information of the respondents such as age, gender, a position held, educational attainment, work experience, and organization size. Section two includes questions are designed to measure the variables of the study by using a comparative seven-point Likert-type scale ranging from 1-7, in which $(1=$ strongly disagree, $7=$ strongly agree $)$. The variables used in this study were assessed using multiple items from different studies in the extant literature.

Human resource development: was operationalized as a four-dimensional construct: talent development, training and development, organizational development, and career development. 20 items are designed to measure HRD constructs by employing five items for each construct respectively, these items were adopted from (Mahfoozi et al.,2018),( Asfaw et al.2015),( Spirina,2015), (Zadeha \& Ghahremanib, 2016), (Xueling,2017), (Weng\&McElroy, 2012).

Dynamic capabilities: dynamic capability was operationalized by three dimensions: sensing capability, learning capability, integrating capability. 15 items are designed to measure dynamic capabilities constructs by employing five items for each construct respectively. The items were adapted from (Teece et al., 1997), (Eisenhardt and Martin, 2000), (Nieves\& Haller, 2014).

Organizational effectiveness: was measured by three approaches: goal approach, system resource approach, and competing values approach. 12 items were used to measure organizational effectiveness by employing four items for each construct respectively. The items were adapted from (Gold et al., 2001), (Rahman et al., 2013), ( Banat,2002),( Abu el Khair,2016). Also, Cronbach 's alpha coefficient was used to evaluate the internal consistency of the scales where Cronbach 's alpha coefficient for all the constructs ranges between 0.874 and 0.962 and it is considered acceptable which indicates that all the items 
are internally consistent. Table (2) shows detailed information regarding the variables, sources, number of the items and Cronbach's alpha.

Table 2: The study measures in regard to the variables, sources, and Cronbach's alpha

\begin{tabular}{|c|c|c|c|c|}
\hline \multicolumn{2}{|c|}{ variables } & Source & Number of & Cronbach's \\
\hline \multirow{4}{*}{$\begin{array}{l}\text { Human Resource } \\
\text { Development }\end{array}$} & Talent development & (Mahfoozi et al., 2018) & 5 & 0.946 \\
\hline & Training and development & (Asfaw et al., 2015) & 5 & 0.932 \\
\hline & Organizational development & $\begin{array}{c}\text { (Rastgoo, 2016) and (Zadeha \& } \\
\text { Ghahremanib, 2016) }\end{array}$ & 5 & 0.947 \\
\hline & Career development & $\begin{array}{c}\text { (Weng \& McElroy, 2012) and } \\
\text { (Xueling, 2017) }\end{array}$ & 5 & 0.953 \\
\hline \multirow{3}{*}{$\begin{array}{l}\text { Dynamic Capabil- } \\
\text { ities }\end{array}$} & Sensing capability & \multirow{3}{*}{$\begin{array}{c}\text { Teece et al. ,1997);( Eisenhardt } \\
\text { and Martin ,2000);( Nieves\&Hal- } \\
\text { ler,2014) }\end{array}$} & 5 & 0.924 \\
\hline & Learning capability & & 5 & 0.962 \\
\hline & Reconfiguring capability & & 5 & 0.938 \\
\hline \multirow{3}{*}{$\begin{array}{l}\text { Organizational } \\
\text { Effectiveness }\end{array}$} & Goal approach & (Banat,2002) & 4 & 0.931 \\
\hline & System resource approach & (Abu El Khair, 2016) & 4 & 0.874 \\
\hline & Competing values approach & $\begin{array}{l}\text { (Gold et al., 2001),(Rahman et al., } \\
\text { 2013) }\end{array}$ & 4 & 0.936 \\
\hline
\end{tabular}

\section{Results}

\subsection{Descriptive statistics}

Table 3 shows a descriptive analysis (mean and standard deviation) of the data and the correlations matrix among variables. The means score for all the constructs is located between (3.29-3.80) and standard deviation (1.48-1.62) that indicates a good implementation of HRD practices and dynamic capabilities in enhancement organizational effectiveness in the selected public universities of Iraq. Also, the results show that each of the constructs is positively and significantly correlated with each other.

\subsection{Measurement model}

To assess the validity of the measurement model and to test the fitting of the data with the proposed model confirmatory factor analysis (CFA) was used to assess the fitness of a measurement model. This study used some indexes like CMIN/df, GFI, TLI, CFI, and RMSEA to investigate the goodness of fit of the model. Table 4 presents the results of the index of confirmatory factor analysis. The results indicate that the goodness-of-fit indicators of all three models are satisfied with the suggested threshold value by (Jacob et al., 2003) thus, indicated good model fitness. 
Table 3: Descriptive and correlation results

\begin{tabular}{|c|c|c|c|c|c|c|c|c|c|c|c|c|c|c|c|}
\hline & Mean & S. D & $\mathrm{TD}$ & $\mathrm{T} \& \mathrm{D}$ & OD & $\mathrm{CD}$ & $\mathrm{SC}$ & LC & $\mathrm{RC}$ & GA & SRA & CVA & HRD & DCs & $\mathrm{OE}$ \\
\hline TD & 3.29 & 1.59 & 1.0 & & & & & & & & & & & & \\
\hline$T \& D$ & 3.49 & 1.56 & $.77 * *$ & 1.0 & & & & & & & & & & & \\
\hline OD & 3.46 & 1.60 & $.77 * *$ & $.82 * *$ & 1.0 & & & & & & & & & & \\
\hline $\mathrm{CD}$ & 3.35 & 1.59 & $.75^{* *}$ & $.79 * *$ & $.83 * *$ & 1.0 & & & & & & & & & \\
\hline $\mathrm{SC}$ & 3.38 & 1.53 & $.79 * *$ & $.79^{* *}$ & $.84^{* *}$ & $.80^{* *}$ & $1.0^{* *}$ & & & & & & & & \\
\hline $\mathrm{LC}$ & 3.41 & 1.54 & $.80^{* *}$ & $.81^{* *}$ & $.86^{* *}$ & $.84 * *$ & $.88^{* *}$ & 1.0 & & & & & & & \\
\hline $\mathrm{RC}$ & 3.53 & 1.56 & $.77 * *$ & $.81^{* *}$ & $.84 * *$ & $.79 * *$ & $.84^{* *}$ & $.86^{* *}$ & 1.0 & & & & & & \\
\hline GA & 3.80 & 1.62 & $.73 * *$ & $.83 * *$ & $.85 * *$ & $.78 * *$ & $.80^{* *}$ & $.84 * *$ & $.84 * *$ & 1.0 & & & & & \\
\hline SRA & 3.44 & 1.48 & $.70 * *$ & $.79 * *$ & $.76 * *$ & $.71 * *$ & $.77 * *$ & $.85 * *$ & $.82 * *$ & $.85 * *$ & 1.0 & & & & \\
\hline CVA & 3.80 & 1.53 & $.62 * *$ & $.69 * *$ & $.70^{* *}$ & $.69 * *$ & $.67 * *$ & $.72 * *$ & $.73 * *$ & $.77 * *$ & $.74 * *$ & 1.0 & & & \\
\hline HRD & 3.39 & 1.58 & $.90^{* *}$ & $.92 * *$ & $.93^{* *}$ & $.92 * *$ & $.87^{* *}$ & $.90^{* *}$ & $.87^{* *}$ & $.87^{* *}$ & $.80^{* *}$ & $.74 * *$ & 1.0 & & \\
\hline DCs & 3.44 & 1.54 & $.82 * *$ & $.84^{* *}$ & $.88^{* *}$ & $.85^{* *}$ & $.95^{* *}$ & $.96^{* *}$ & $.94 * *$ & $.87^{* *}$ & $.85^{* *}$ & $.74 * *$ & $.92^{* *}$ & 1.0 & \\
\hline $\mathrm{OE}$ & 3.68 & 1.54 & $.73 * *$ & $.83 * *$ & $.83 * *$ & $.79 * *$ & $.80^{* *}$ & $.87 * *$ & $.86^{* *}$ & $.94^{* *}$ & $.93 * *$ & $.90 * *$ & $.87 * *$ & $.88^{* *}$ & 1.0 \\
\hline
\end{tabular}

**. Correlation is significant at the 0.01 level (2-tailed).

$\mathrm{HRD}=$ Human Resource Development, DCs=Dynamic Capabilities, OE=Orginzational Effectiveness, TD=Talent Development, $\mathrm{T} \& \mathrm{D}=$ Training \& Development, $\mathrm{OD}=$ Organizational Development, $\mathrm{CD}=$ Career Development $\mathrm{SC}=\mathrm{Sensing}$ Capability, $\mathrm{LC}=$ learning Capability= Reconfiguring Capability, GA=Goal Approach, SRA=System Resource Approach, CVA=Competing Values Approach. Measurement Items used for calculation of the listed variables are explained in $\lceil$ Appendix 1.

Table 4: Index of confirmatory factor analysis

\begin{tabular}{|l|c|c|c|}
\hline & HRD model & DC model & OE model \\
\hline CMIN/df & 1.895 & 1.547 & 1.828 \\
\hline GFI & 0.874 & 0.883 & 0.900 \\
\hline TLI & 0.931 & 0.970 & 0.955 \\
\hline CFI & 0.944 & 0.978 & 0.973 \\
\hline RMSEA & 0.0721 & 0.073 & 0.070 \\
\hline
\end{tabular}

\subsection{Reliability and Validity}

In this study and before testing the hypotheses reliability and validity of measurement scales were assessed by using confirmatory factor analysis (CFA), and AMOS 24 was used to estimate convergent validity and discriminant validity. The reliability of the scales was evaluated using Cronbach's alpha coefficient as it is seen in table 2, Cronbach's alpha coefficient for all constructs ranges between 0.874 and 0.962 and it is considered acceptable which indicates that all the items are internally consistent (Hair et al., 2010). In order to determine the convergent validity, there are three important indicators of convergent validity which are factor loadings (standardized estimates), Aver- age Variance Extracted (AVE) and Composite Reliability (CR). Hair et al., (2006) suggests that the items with loadings in between .50 to .70 can be maintained. This study investigates that the item loadings all exceeded the threshold value and statistically significant $(\mathrm{p}<0.05)$ (see table 4). Composite reliability (CR) for all constructs ranges between 0.767 and 0.955 which are above 0.50 that indicates that all the constructs have a good level of composite reliability (CR) as recommended by (Hair et al., 2012). The average variance extracted (AVE) value for all the constructs are in the range between .632 to .827 which are above the threshold value .50 which is suggested by (Hair et al., 2010). 
Table 5: Constructs evaluation

\begin{tabular}{|c|c|c|c|c|c|}
\hline Constructs & $\begin{array}{c}\text { Measurement } \\
\text { Items }\end{array}$ & $\begin{array}{l}\text { Factor } \\
\text { Loading }\end{array}$ & $\mathrm{CR}$ & AVE & P.Value \\
\hline \multirow{5}{*}{ Talent Development } & TD5 & 0.852 & \multirow{5}{*}{0.947} & \multirow{5}{*}{0.780} & .000 \\
\hline & TD4 & 0.884 & & & .000 \\
\hline & TD3 & 0.896 & & & .000 \\
\hline & TD2 & 0.898 & & & .000 \\
\hline & TD1 & 0.852 & & & .000 \\
\hline \multirow{5}{*}{ Training \&Development } & T_D5 & 0.807 & \multirow[b]{5}{*}{0.932} & \multirow[b]{5}{*}{0.732} & .000 \\
\hline & T_D4 & 0.902 & & & .000 \\
\hline & T_D3 & 0.886 & & & .000 \\
\hline & T_D2 & 0.855 & & & .000 \\
\hline & T_D1 & 0.827 & & & .000 \\
\hline \multirow{5}{*}{$\begin{array}{c}\text { Organizational Deve- } \\
\text { lopment }\end{array}$} & OD5 & 0.900 & \multirow[b]{5}{*}{0.948} & \multirow[b]{5}{*}{0.785} & .000 \\
\hline & OD4 & 0.900 & & & .000 \\
\hline & OD3 & 0.904 & & & .000 \\
\hline & OD2 & 0.875 & & & .000 \\
\hline & OD1 & 0.850 & & & .000 \\
\hline \multirow{5}{*}{ Career Development } & CD5 & 0.854 & \multirow[b]{5}{*}{0.955} & \multirow[b]{5}{*}{0.808} & .000 \\
\hline & CD4 & 0.952 & & & .000 \\
\hline & CD3 & 0.904 & & & .000 \\
\hline & $\mathrm{CD} 2$ & 0.922 & & & .000 \\
\hline & CD1 & 0.861 & & & .000 \\
\hline \multirow[t]{5}{*}{ Sensing Capability } & $\mathrm{SC} 1$ & 0.769 & \multirow[t]{5}{*}{0.767} & \multirow[t]{5}{*}{0.709} & .000 \\
\hline & $\mathrm{SC} 2$ & Deleted & & & .000 \\
\hline & $\mathrm{SC} 3$ & 0.769 & & & .000 \\
\hline & $\mathrm{SC} 4$ & 0.915 & & & .000 \\
\hline & SC5 & 0.876 & & & .000 \\
\hline \multirow[t]{5}{*}{ Learning Capability } & $\mathrm{LC} 1$ & 0.875 & \multirow[t]{5}{*}{0.899} & \multirow[t]{5}{*}{0.827} & .000 \\
\hline & $\mathrm{LC} 2$ & 0.871 & & & .000 \\
\hline & LC3 & 0.919 & & & .000 \\
\hline & $\mathrm{LC} 4$ & 0.961 & & & .000 \\
\hline & $\mathrm{LC} 5$ & 0.918 & & & .000 \\
\hline \multirow{5}{*}{$\begin{array}{l}\text { Reconfiguration } \mathrm{Ca}- \\
\text { pability }\end{array}$} & $\mathrm{RC} 1$ & 0.818 & \multirow[t]{5}{*}{0.837} & \multirow[t]{5}{*}{0.762} & .000 \\
\hline & $\mathrm{RC} 2$ & 0.783 & & & .000 \\
\hline & $\mathrm{RC} 3$ & 0.938 & & & .000 \\
\hline & $\mathrm{RC} 4$ & 0.951 & & & .000 \\
\hline & RC5 & 0.863 & & & .000 \\
\hline
\end{tabular}


Table 5: Constructs evaluation (continued)

\begin{tabular}{|c|c|c|c|c|c|}
\hline \multirow[t]{4}{*}{ Goal Approach } & GA4 & 0.901 & \multirow[b]{4}{*}{0.932} & \multirow[b]{4}{*}{0.789} & .000 \\
\hline & GA3 & 0.837 & & & .000 \\
\hline & GA2 & 0.904 & & & .000 \\
\hline & GA1 & 0.910 & & & .000 \\
\hline \multirow{4}{*}{$\begin{array}{l}\text { System Resource } \\
\text { Approach }\end{array}$} & SRA4 & 0.883 & \multirow[b]{4}{*}{0.872} & \multirow[b]{4}{*}{0.632} & .000 \\
\hline & SRA3 & 0.733 & & & .000 \\
\hline & SRA2 & 0.722 & & & .000 \\
\hline & SRA1 & 0.797 & & & .000 \\
\hline \multirow{4}{*}{$\begin{array}{l}\text { Competing Values } \\
\text { Approach }\end{array}$} & CVA4 & 0.904 & \multirow[b]{4}{*}{0.936} & \multirow[b]{4}{*}{0.772} & .000 \\
\hline & CVA3 & 0.940 & & & .000 \\
\hline & CVA2 & 0.824 & & & .000 \\
\hline & CVA1 & 0.841 & & & .000 \\
\hline
\end{tabular}

$\mathrm{CR}=$ Composite Reliability and Average, $\mathrm{AVE}=$ Variance Extracted

Discriminant validity was assessed by using two methods: First,(Fornell \& Larcker, 1981) method. He suggested that to support for discriminant validity if the square root of the AVE for a latent construct is greater than the correlation values among all the latent variables. Table (5) shows that the square root of the AVE values of all the constructs is greater than the inter-construct correlations which sup- ports the discriminant validity of the constructs. Second, (Hair et al., 2010) he suggests if AVE for a latent construct is larger than the maximum shared variance with other latent constructs that indicates discriminant validity can be maintained Thus, the measurement model indicates a good construct validity and desirable psychometric properties.

Table 6: Discriminant validity of the constructs

\begin{tabular}{|l|l|l|l|l|l|l|l|l|l|l|l|l|}
\hline & AVE & MSV & TD & T_D & OD & CD & SC & LC & RC & GA & SRA & CVA \\
\hline TD & 0.780 & 0.682 & $\mathbf{0 . 8 8 3}$ & & & & & & & & & \\
\hline T_D & 0.732 & 0.706 & 0.823 & $\mathbf{0 . 8 5 5}$ & & & & & & & & \\
\hline OD & 0.785 & 0.749 & 0.816 & 0.817 & $\mathbf{0 . 8 8 6}$ & & & & & & & \\
\hline CD & 0.808 & 0.664 & 0.785 & 0.827 & 0.866 & $\mathbf{0 . 8 9 8}$ & & & & & & \\
\hline SC & 0.709 & 0.697 & 0.532 & 0.721 & 0.781 & 0.421 & $\mathbf{0 . 8 4 2}$ & & & & & \\
\hline LC & 0.827 & 0.807 & 0.621 & 0.608 & 0.801 & 0.305 & 0.723 & $\mathbf{0 . 9 0 9}$ & & & & \\
\hline RC & 0.762 & 0.714 & 0.712 & 0.512 & 0.601 & 0.541 & 0.801 & 0.621 & $\mathbf{0 . 8 7 2}$ & & & \\
\hline GA & 0.789 & 0.701 & 0.798 & 0.836 & 0.821 & 0.850 & 0.721 & 0.653 & 0.812 & $\mathbf{0 . 8 8 8}$ & & \\
\hline SRA & 0.632 & 0.501 & 0.788 & 0.648 & 0.771 & 0.708 & 0.765 & 0.541 & 0.700 & 0.695 & $\mathbf{0 . 7 9 5}$ & \\
\hline CVA & 0.772 & 0.727 & 0.068 & 0.744 & 0.754 & 0.737 & 0.321 & 0.652 & 0.756 & 0.691 & 0.609 & $\mathbf{0 . 8 8 6}$ \\
\hline
\end{tabular}

Notes: Bold values in diagonal represent the squared root estimate of AVE. AVE= Average Variance Extracted, MSV= Maximum shared variance 


\subsection{Common method bias Checks}

Due to this research is employed a cross-sectional with a self-report questionnaire, common method variance (CMV) may affect systematic measurement accuracy (Podsakoff and Organ, 1986). Harman's single-factor test was used to address this issue by using exploratory factor analysis (EFA). The results show that the total variance for a single factor is less than $50 \%$ which means that common method bias does not confound the interpretations of the results.

\subsection{The structural model: test of hypotheses}

\subsubsection{The direct effects}

Structured equation modeling (SEM) was used to test the hypothesized model. The results of the proposed structural model show the good fit $(\mathrm{CMIN} / \mathrm{df}=1.418, \mathrm{GFI}=0.925$, $\mathrm{TLI}=0.986, \mathrm{CFI}=0.990, \mathrm{RMSEA}=0.064$ ). In order to verify the following hypotheses, H1, H2, H3 direct effects were assessed. The results, presented in (Figure 2 and Table 5) indicate that the three hypotheses are supported. In particular, HRD practices have a significant impact on organizational effectiveness $(\beta=0.390, p<0.001)$ supporting H1. Similarly, the results revealed that HRD practices have a significant impact on the dynamic capabilities $(\beta=0.982$, $\mathrm{p}<0.001$ ), therefore the hypothesis $\mathrm{H} 2$ is supported. Also, the results confirmed that dynamic capabilities significantly influence organizational effectiveness $(\beta=0.568$, $\mathrm{p}<0.001$ ) which is supporting the hypothesis $\mathrm{H} 3$.

Table 7: Results of direct effects

\begin{tabular}{|l|l|c|c|c|}
\hline NO. & \multicolumn{1}{|c|}{ Hypotheses path } & $\begin{array}{c}\text { Beta Coeffi- } \\
\text { cient }\end{array}$ & P. Value & Result \\
\hline H1 & HRD $\rightarrow$ OE & 0.390 & 0.001 & Supported \\
\hline H2 & HRD $\rightarrow$ DC & 0.982 & 0.001 & Supported \\
\hline H3 & DC $\rightarrow$ OE & 0.568 & 0.001 & Supported \\
\hline
\end{tabular}

Table 8: Results of mediating effect

\begin{tabular}{|c|c|c|c|c|c|c|}
\hline NO. & Hypotheses path & Beta Coefficient & P. Value & $95 \% \mathrm{LL}$ & $95 \% \mathrm{UL}$ & Result \\
\hline $\mathrm{H} 4$ & HRD $\rightarrow \mathrm{DC} \rightarrow \mathrm{OE}$ & 0.558 & 0.001 & 0.073 & 0.533 & Supported \\
\hline
\end{tabular}

Hypothesis is supported, when there is no zero between lower and upper limits, LL: Lower limit, UL: Upper

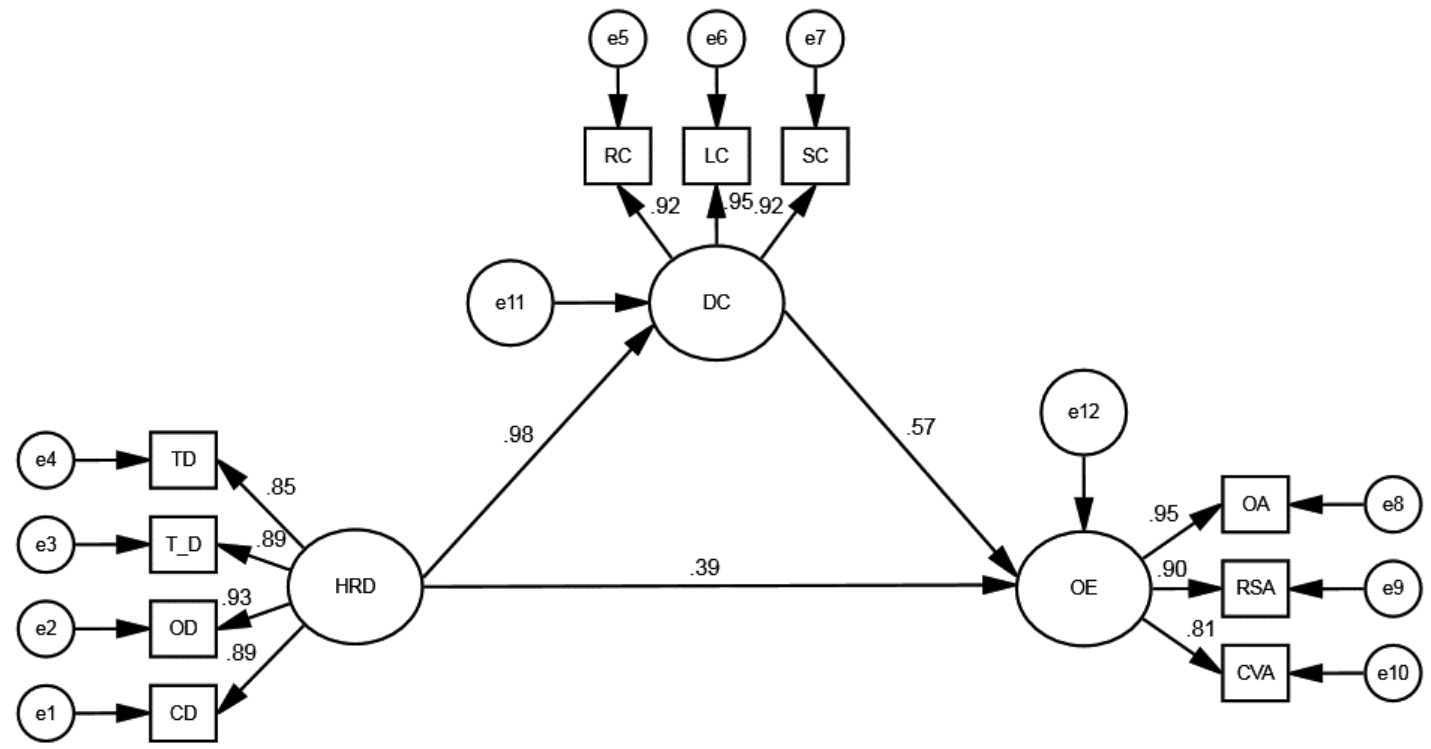

Figure 2: The SEM model analysis 


\subsubsection{The mediating effects}

In order to test hypothesis $\mathrm{H} 4$ indirect effect was assessed. The results showed in table 6 indicate that dynamic capabilities are significantly mediate the relationship between HRD practices and organizational effectiveness $(\beta=0.558$, $\mathrm{p}<0.001)$. Also, the bootstrapping was used in order to calculate the $95 \%$ confidence interval of the indirect. The results show there is no zero between lower and upper limits which is provided evidence that hypothesis $\mathrm{H} 4$ is supported.

\section{Discussion and Conclusions}

Due to limited studies in the literature, there is still confusion about how the impact of HRD practices on organizational effectiveness through the mechanisms of dynamic capabilities. The aim of this study is to investigate the mediating role of dynamic capabilities in the relationship between HRD practices and organizational effectiveness in the selected Iraqi public universities context. This study proposed a causal model that explains the relationship between HRD practices and organizational effectiveness through the role played by dynamic capabilities. The present study found out four key findings. First, HRD practices significantly influence organizational effectiveness which is in line with the suggestions of (Mohammed 2006; Alagaraja et al., 2015; and Shoo 2016). Second, HRD practices have a significant impact on dynamic capabilities which is in line with the opinions of (Garavan et al.,2016; Yan and Gao,2016 and Teece, 2007). Third, dynamic capabilities significantly influence organizational effectiveness which is consistent with (Zhou,2017; Fainshmidt et al., 2016 and Teece et al, 1997). Fourth, dynamic capabilities significantly mediate the relationship between HRD practices and organizational effectiveness which is in line with the opinions (Zollo and Winter 2002; Aminu and Mahmood, 2015). In conclusion, this study argues that the relationship between HRD practices and organizational effectiveness is not direct in changing business environments but through the mediating role of dynamic capabilities. Consequently, in such shifts and turbulences in business environments, organizations need to develop not only a human resource but also dynamic capabilities for sensing environmental conditions, learning response patterns and reconfiguring operating routines, in turn, organizations will be able to achieve superior organizational effectiveness.

\subsection{Theoretical contributions of the study}

Regarding the theoretical contribution, this study provides a research model for empirical literature in the field of human resource devolvement, dynamic capabilities, and organizational effectiveness. Specifically, this study developed a model to investigate the direct relationship between HRD and organizational effectiveness and dynamic capabilities and the relationship between dynamic capabilities and organizational effectiveness as well as to examine the mediating role of dynamic capabilities on the relationship between HRD and organizational effectiveness. The results from a structural equation modeling approach have confirmed all the hypothesized relations. The results show that HRD practices significantly impact on organizational effectiveness and dynamic capabilities. The study shows that dynamic capabilities have a positive impact on organizational effectiveness. Also, the study empirically supports the mediating effect of dynamic capabilities on the relationship between HRD practices and organizational effectiveness. Despite of, that HRD, dynamic capabilities and organizational effectiveness have attracted considerable attention in the literature but, only very limited studies have highlighted the mediating role of HRD capabilities in the relationships between HRD and organizational effectiveness. Therefore, the empirical findings of this study have potential significant to fill the gap in the literature.

\subsection{Managerial implications of the study}

Besides the theoretical implications, this study provides practical implications for universities management, the present study provides significant insight and demonstrates a good understanding of HRD practices, dynamic capabilities and organizational effectiveness in the selected Iraqi public universities context. The findings of this study have the potential to help decision-makers to design their HRD practices to contribute to enhance organizational effectiveness. The study brings universities management closer to understand the role of dynamic capabilities to integrate, build, and reconfigure internal and external competencies to address rapidly changing environments, in turn, support make decisions within the organization which has the potential to enhance organizational effectiveness and performance. In such an environment, universities management should develop not only HRD practices but, also adopt dynamic capabilities mechanisms to improve organizational effectiveness.

\subsection{Limitations and future research}

Despite of the theoretical and managerial contributions, this study has some limitations that need to be addressed in future research. First, this study focuses on the top ten Iraqi public universities context, which may not be exclusively generalizable to other sectors. Therefore; future research may investigate this phenomenon in other businesses and economic context. Second, the sample of the study somewhat is small because of the unsafe situation in Iraq the 
authors couldn't get an appropriate sample. However, future research may conduct in big enough and appropriate sample. Third, this study adopts a cross-sectional research method for data collection, which does not allow the researcher to examine the causality of the relationships between the variables in greater depth. Thus, future research should aim to use longitudinal data which could explain the highlighted relationships more insights. Fourth, this study focuses on four dimensions of HRD, three dimensions of dynamic capabilities and three dimensions of organizational effectiveness, therefore, future research may include other potential dimensions. The findings of this study are limited to the selected Iraqi public universities context and cannot be generalized to other countries and other businesses context.

\section{Literature}

Abu El Khair, R. H. (2016). Productive university requirements, And their relationship with Organizational effectiveness in technical colleges in Gaza Governorates. Gaza: Al Azhar University. Adhikari, D. R. (2010). Human resource development(HRD) for performance management: The case of Nepalese organizations. International Journal of Productivity and Performance Management, 59 (4), https://doi.org/10.1108/17410401011038883

Agwu, M. O., \& Ogiriki, T. (2014 ). Human Resource Development and Organizational Performance in the Nigeria Liquefied Natural Gas Company Limited, Bonny. Journal of Management and Sustainability, 4(4), https://doi.org/10.5539/jms.v4n4p134

Alagaraja, M., Cumberland, D., \& Choi, N. (2015). The mediating role of leadership and people management practices on HRD and organizational performance. Human Resource Development International, 18, 220234, https://doi.org/10.1080/13678868.2014.997139

Aminu, M. I., \& Mahmood, R. (2015). Mediating Role of Dynamic Capabilities on the Relationship between Intellectual Capital and Performance: A Hierarchical Component Model Perspective in PLS-SEM Path Modeling. Research Journal of Business, 9 (3), 443-456, https://doi.org/10.3923/rjbm.2015.443.456

Asfaw, A. M., Argaw, M. D., \& Bayissa, L. (2015). The Impact of Training and Development on Employee Performance and Effectiveness: A Case Study of District Five Administration Office, Bole Sub-City, Addis Ababa, Ethiopia. Journal of Human Resource and Sustainability Studies, 3, 188202.

https://doi.org/10.4236/jhrss.2015.34025

Banat, M. S. (2002). Organizational Effectiveness of Palestinian Universities The Islamic University of Gaza - A case study. Gaza: The Islamic University of Gaza.

Barney, J. B. (1991). Firm resources and sustained competitive advantage. Journal of Management, 17(1), 99-
120, https://doi.org/10.1177/014920639101700108

Brockbank, W. (1999). If HR Were Really Strategically Proactive: Present and Future Directions in HR's Contribution to Competitive Advantage. $\mathrm{Hu}$ man Resource Management, 38 (4): 337-352.

Chengcheng, J. (2010). The Effect of Human Resource Management Practices on firm's Competitive Advantage: Role of Dynamic Capabilities and Uncertain Environment. IEEE International Conference on Advanced Management Science. Chengdu, China: IEEE.

Clardy, A. (2008). The Strategic Role of Human Resource Development in Managing Core Competencies. $\mathrm{Hu}$ man Resource Development International, 11 (2), 183197, https://doi.org/10.1080/13678860801932998

Creswell, J. W. (2013). Research design: Qualitative, quantitative, and mixed methods approaches (2nd ed.). Thousand Oaks, CA: Sage.

Eisenhardt, K. M., \& Martin, J. A. (2000). Dynamic capabilities: What are they? Strategic Management Journal, 21(10-11), 1105-1121, https://doi. org/10.1002/1097-0266(200010/11)21:10/11\%3C1 105 : : A I D - S M J $133 \% 3$ E 3 . 0 . C O ; 2 - E

Fainshmidt, S., Pezeshkan, A., Frazier, M. L., Nair, A., \& Markowski, E. P. (2016). Dynamic Capabilities and Organizational Performance: A Meta-Analytic Evaluation and Extension. Journal of Management Studies, 53(8), https://doi.org/10.1111/joms.12213

Fornell, C., \& Larcker, D. (1981). Structural equation models with unobservable variables and measurement error: Algebra and statistics. Journal of marketing research, 18(3), 382-388, https://doi.org/10.1177\%2F002224378101800313

Garavan, T. (2007). A Strategic Perspective on HRD. Advances in Developing Human Resources, 9(1): 11-30, https://doi.org/10.1177/1523422306294492

Garavan, T. N., Shanahan, V., Carbery, R., \& Watson, S. (2016). Strategic human resource development: Towards a conceptual framework to understand its contribution to dynamic capabilities. Human Resource Development International, 19(4), 289-306, https://doi.org/10.1080/13678868.2016.1169765

Gberevbie, D. E. ( 2012). Impact of human resource development and organizational commitment on financial sector employees in Nigeria. Scientific Annals of Economics and Business, 59 (2), 29-4, http://doi.org/10.2478/v10316-012-0030-9

Gold, A., Malhotra, A., \& Segars, A. (2001). Knowledge management: an organizational capabilities perspective. Journal of Management Information Systems, 18(1), 185-214, https://doi.org/10.1080/07421222.2001.11045669

Grant, R. M. (1996). Toward a knowledge-based theory of the firm. Strategic Management Journal, 17(2), 109-122, https://doi.org/10.1002/smj.4250171110

Grohmann, A., \& Kauffeld, S. (2013). Evaluating Training Programs: Development and Correlates of the 
Questionnaire for Professional Training Evaluation. International Journal of Training and Development, 17, 135-155, https://doi.org/10.1111/ijtd.12005 Hair, J., Black, W., Babin, B., \& Anderson, R. \&. (2006). Multivariate data analysis. Upper Saddle River, NJ: Pearson Prentice Hall. Hair, J.F., Black, W.C., B., \& B.J. and Anderson, R. (2010). Multivariate data analysis: a global perspective. Delhi: Pearson Education.

Hair, J.F., Sarstedt, M., Ringle, C., \& Mena, J. (2012). An assessment of the use of partial least squares structural equation modeling in marketing research. Journal of the academy of marketing science, 40(3), 414-433, http://doi.org/10.1007/s11747-011-0261-6

Hammer, M. (2001). The agenda: What every business must do to dominate the decade. NY: Crown Publishers.

Han, J. P. (2006). The HR Competencies-HR Effectiveness Link: A Study in Taiwanese High-Tech Companies. Human Resource Management, 45(3), 391-406, https://doi.org/10.1002/hrm.20114

Helfat, C. F. (2007). Dynamic Capabilities: Understanding Strategic Change in Organizations. Oxford: Blackwell Publishing.

Henson, R. K., \& Roberts., J. K. (2006). Use of Exploratory Factor Analysis in Published Research Common Errors and Some Comment on Improved Practice. Educational and Psychological Measurement, 66(3), 393416, http://dx.doi.org/10.1177/0013164405282485

Hsu, L.-C., \& Wang, C.-H. (2012). Clarifying the Effect of Intellectual Capital on Performance: The Mediating Role of Dynamic Capability. British Journal of Management, 23 (2), 179-205, http://doi.org/10.1111/j.1467-8551.2010.00718.x

Jacob, A. D. ( 2003). Validation of a short questionnaire to assess the degree of complexity and structuredness of PBL problems. Medical Education, 37, 1001-1007, https://doi.org/10.1046/j.1365-2923.2003.01630.x

Lado, A., \& Wilson, M. (1994). Human resource systems and sustained competitive advantage: a competency-based perspective. The Academy of Management Review, 19(4), 669-727, http://doi.org/10.2307/258742

Lee, S.-M. T.-S. (2014). The effect of knowledge management capability and dynamic capability on organizational performance. Journal of Enterprise Information Management, 27(2), 158179, https://doi.org/10.1108/JEIM-05-2012-0025

Lepak, D. P., \& Snell, S. A. (1999). The Human Resource Architecture: Toward a Theory of Human Capital Allocation and Development. The Academy of Management Review, 24(1), 31-48, http://doi.org/10.2307/259035

López, S. (2005). Competitive advantage and strategy formulation, The key role of dynamic capabilities. Management Decision, 43(5-6), 661669, http://doi.org/10.1108/00251740510597699

Lopez-Cabrales, A., Bornay-Barrachina, M., and Diaz-Fernandez, M. (2017). Leadership and dynamic capabili- ties: the role of HR systems, Personnel Review, 46(2), 255-276, https://doi.org/10.1108/PR-05-2015-0146 Mahfoozi, A., Salajegheh, S., Ghorban, M., \& Sheikhi, a. A. (2018). Developing a talent management model using government evidence from a large-sized city, Iran. Cogent Business \& Management, 5(1), 1-15, https://doi.org/10.1080/23311975.2018.1449290

McCracken, M., \& Wallace., M. (2000). Exploring Strategic Maturity in HRD - Rhetoric, Aspiration or Reality?". Journal of European Industrial Training, 24(8), 425-426, https://doi.org/10.1108/03090590010354344

Mohammed, I. (2006). Personnel performance evaluation: A conceptual index for the management and development of Nigerian oil and gas industry. Petroleum Training Journal, 3(1), 24-31. Nieves, J., \& Haller, S. (2014). Building dynamic capabilities through knowledge resources. Tourism Management, 40 (1), 224-232, http://doi.org/10.1016/j.tourman.2013.06.010

Nilsson, S., \& Ellstrom, P. E. (2012). Employability and talent management: challenges for HRD practices. European Journal of Training and Development, 36, 26-45, https://doi.org/10.1108/03090591211192610

Otoo, F. N., \& Mishra, M. (2018). Influence of Human Resource Development (HRD) Practices on Organizational Effectiveness: The Role of Employee Competencies. International Journal of Management Studies, $\mathrm{V}(2)$, http://dx.doi.org/10.18843/ijms/v5i2(6)/13

Otoo, F. N., Otoo, E. A., Abledu, G. K., \& Bhardwaj, A. (2019). Impact of human resource development (HRD) practices on pharmaceutical industry's performance: The mediating role of employee performance. European Journal of Training and Development, 43(1/2), https://doi.org/10.1108/EJTD-09-2018-0096

Pavlou, P. A., \& Sawy, O. A. (2011). Understanding the Elusive Black Box of Dynamic Capabilities. Decision Sciences Journal, 42(1), 239-273, https://doi.org/10.1111/j.1540-5915.2010.00287.x

Podsakoff, P. M., \& Organ, D. W. (1986). Self-reports in organizational research: Problems and prospects. Journal of Management, 12(1), 531-544.

Rahman, A. I. (2013). Training and organizational effectiveness: moderating role of knowledge management process. European Journal of Training and Development, 37(5), 472-488, https://doi.org/10.1108/03090591311327295

Rehman, K. U., \& Saeed, Z. (2015). Impact of Dynamic Capabilities on Firm Performance: Moderating Role of Organizational Competencies. Sukkur Journal of Business Administration, 2(2), $\quad$ http://doi.org/10.30537/sijmb.v2i2.92

Riordan, C. M., Vandenberg, R. J., \& Richardson, H. A. (2005). Employee involvement climate and organizational effectiveness. Human Resource Management, 44(4), 471-488, https://doi.org/10.1002/hrm.20085 Sabarina, M. (2015). The impact of human resources de- 
velopment strategy on the performance of individuals: teachers as well as administrative workers in universities. Biskra, Algeria: Mohamed Khider University.

Sahoo, R. K. (2016). HRD interventions, employee competencies and organizational effectiveness: an empirical study". European Journal of Training and Development, 40(5), https://doi.org/10.1108/EJTD-02-2016-0008

Sekaran, U., \& Bougie, R. (2013). Research Methods for Business: A Skill-Building Approach. 6th Edition. New York: Wiley. Shanahan, V., Garavan, T., \& Carbery, R. (2012). Strategic Human Resource Development and Dynamic Capabilities. Leadership and Management Development conference. University Forum for Human Resource Development.

Swanson, R., \& Holton, E. (2009). Foundations of Human Resource Development.2nd Edition. San Francisco: Berrett-Koehler.

Takahashi, A. R., \& Giacomini, E. S. (2016). Dynamic capabilities, Marketing Capability, and Organizational Performance. Brazilian Business Review, 14(5), http://doi.org/10.15728/bbr.2017.14.5.1

Teece, D. J. (2007). Explicating dynamic capabilities: the nature and micro-foundations of (sustainable) enterprise performance. Strategic Management Journal, 28(13), 1319-1350, https://doi.org/10.1002/smj.640

Teece, D. J.,\& Pisano, G. a. (1997). Dynamic capabilities and strategic management. Strategic Management Journal, 18(7), 509-533, https://doi.org/10.1002/(SICI)10970266(199708)18:7<509::AID-SMJ882>3.0.CO;2-Z

Wang, C. Y.-P.-S.-C. (2012). Building dynamic strategic capabilities: a human capital perspective. International Journal of Human Resource Management, 23(6), 11291157, http://doi.org/10.1080/09585192.2011.561234

Weng, Q., \& McElroy, J. C. (2012). Organizational career growth, affective occupational lcommitment, and turnover intentions. Journal of Vocational Behavior, 80, 256-265, http://dx.doi.org/10.1016/j.jvb.2012.01.014

Wilden, R. G. (2013). Dynamic capabilities and performance: Strategy, structure, and environment. Long Range Planning, 46(1-2), 72-96, http://dx.doi.org/10.1016/j.lrp.2012.12.001

Wilhelm, H., Schlömer, M., \& Maurer, I. (2015). How Dynamic Capabilities Affect the Effectiveness and Efficiency of Operating Routines under High and Low Levels of Environmental Dynamism. British Journal of Management, 27(2), 327-345, https://doi.org/10.1111/1467-8551.12085

Wright, P. M., \& Snell, S. A. (2009). 'Human resources, organizational resources, and capabilities 'in Storey, $J$. (ed.), The Routledge companion to strategic human resource management. London: Routledge, pp. 345-356.

Wright, P. M., Dunford, B. B., \& Snel, S. A. (2001). Human resources and the resource-based view of the firm. Journal of Management, 27, 701-721, https://doi.org/10.1177/014920630102700607
Xueling,', P. (2017). Empirical Study of Career Management and Engagement. Canadian Social Science, 13(1), 43-48, http://doi.org/10.3968/9239

Yan, G., \& Gao, E. (2016). Dynamic Capabilities Enhancing Path: a Perspective on Human Resource Policy. 6th International Conference on Management, Education, Information and Control. Shenyang, China:Atlantis Press.

Zadeha, L. K., \& Ghahremanib, M. (2016). Factors affecting organizational development (Case Study: Welfare office of East Azerbaijan province). International Academic Journal of Organizational Behavior and Human Resource Management, 3(5), 46-51.

Zahra, S., \& George, G. (2002). The net-enabled business innovation cycle and the evolution of dynamic capabilities. Information Systems Research, 13(2), 147-155, http://doi.org/10.1287/isre.13.2.147.90

Zhou, S., \& Zhou, A. (2017). Dynamic capabilities and organizational performance: The mediating role of innovation. Journal of Management \& Organization, 1- 17, https://doi.org/10.1017/jmo.2017.20

Zollo, M., \& Winter, S. G. (2002). Deliberate learning and the evolution of dynamic capabilities. Organization Science, 13(3), 339-351, https://doi.org/10.1287/orsc.13.3.339.2780

Zott, C. (2003). Dynamic capabilities and the emergence of interindustry differential firm performance: insights from a simulation study. Strategic Management Journal, 24(2), 97-125,. https://doi.org/10.1002/smj.288

Mohanad Ali Kareem is a Ph.D. candidate at Kaposvár University, Faculty of Economic Science, Doctoral School of Management and Organizational Science, Hungary. His research focuses on human resources management, Strategic management, and organizational behavior.

Hayder Abdulmohsin Mijbas is an Assistant Lecturer at Al-Mustansiriya University, Department of Business Administration, Iraq. He is also the director of the Department of Finance of Al-Mustansiriya University. His research focuses on Strategic Management, Operation Management, and Information Management. 


\title{
Appendix: List of Measurement Items
}

\author{
HRD practices: \\ 1.Talent Development \\ TD1. Our universitylinstitute attracts and recruit the right talent \\ TD2. Our universitylinstitute identifies existing talent \\ TD3. Our universitylinstitute nurtures and develop talent \\ TD4. Our universitylinstitute ensures the talent engagement \\ TD5. Our universitylinstitute ensures the talent retention \\ 2.Training and Development \\ T\&D1. Our universitylinstitute has effective training and development programs \\ T\&D2. The activities of training development programs provided enable to improve skills, knowledge, attitude chan- \\ ge, new capability of the employee. \\ T\&D3. The activities of training programs provided help to increase job satisfaction and work efficiency. \\ T\&D4. Our universitylinstitute uses a modern training and development methods and tools. \\ T\&D5. Evaluate the trainees' overall satisfaction with the training program. \\ 3.Organizational Development \\ GD1. Our universitylinstitute makes efforts to development of human resources according to organizational change \\ GD2. Our universitylinstitute encourages the change management \\ GD3. Our universitylinstitute ensures the organizational restructuring \\ GD4. Our universitylinstitute encourages the teamwork \\ GD5. Our universitylinstitute encourages the problem-solving culture \\ 4.Career Development \\ CD1. The organizational structure of the universitylinstitute facilities the career planning and development \\ CD2. Our universitylinstitute offers career counseling. \\ CD3. Our universitylinstitute gives training to help develop my career \\ CD4. Our universitylinstitute has a fair promotion \\ CD5. Our universitylinstitute ensures the growth of remuneration.
}

\section{Organizational effectiveness:}

1.Competing Values Approach

CVA1. Our universitylinstitute makes efforts to improve the productivity

CVA2. Our universitylinstitute adapts to the changing environment

CVA3. Our universitylinstitute makes efforts to the optimization of resources

CVA4. Our universitylinstitute makes efforts to the stability

2.Goal Approach

GA1. Our universitylinstitute ensures goal achievement

GA2. Our universitylinstitute has an effective strategic planning

GA3. Our universitylinstitute encourages the innovation

GA4. Our universitylinstitute makes efforts improve the quality

3.System Resource Approach

SRA1. Our universitylinstitute has the ability to acquire resource

SRA2. Our universitylinstitute has good physical infrastructures and equipment

SRA3. Our universitylinstitute ensure the accreditation

SRA4. Our universitylinstitute encourages the organizational health

\section{Dynamic capabilities}

1.Sensing capability

SC1. Our universitylinstitute conducts environmental assessment to identify new job opportunities

SC2. Our universitylinstitute ensures the performance assessment

SC3. our university/institute dedicates much time to applying ideas for new educational programs and improving existing educational programs

SC4. Our universitylinstitute encourages the collaboration readiness

SC5. Our universitylinstitute encourages the changing and renewal

2.Learning Capabilities

LC1.Our universitylinstitute has effective routines to identify, value, and import new information and knowledge.

LC2.Our universitylinstitute has appropriate routines to assimilate new information and knowledge.

LC3.Our universitylinstitute has effective in transforming existing information into new knowledge. 
LC4.Our universitylinstitute has effective in utilizing knowledge in new services.

LC5.Our universitylinstitute has effective in developing new knowledge that has the potential to influence service 3.Reconfiguration Capabilities

RC1. Our universitylinstitute has a clear human resource re-allocation procedure

RC2. Our universitylinstitute makes efforts to organizational response to environmental changes.

RC3. Our universitylinstitute fasts response to competitor's actions.

RC4. Our universitylinstitute has an effective communication with cooperative organization.

RC5. Our universitylinstitute fasts response to changes in the needs of its clients. 